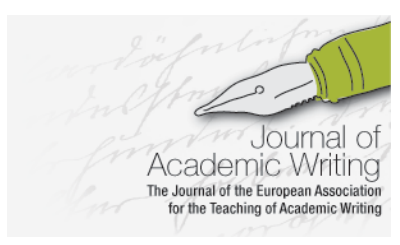

\title{
Technical Writing as Part of Project Management for Engineers: Using a Writing- process Approach to Teach Disciplinary Writing Requirements
}

\author{
Dr Ruth Wiederkehr \\ Independent scholar, Switzerland \\ Dr Marie-Thérèse Rudolf von Rohr \\ University of Applied Sciences and Arts Northwestern Switzerland, Switzerland
}

\begin{abstract}
This article focuses on how formative feedback can be used to help engineering students write precise and coherent management summaries that appeal to a mixed audience. Management summaries are especially challenging to master as students must strive for a balance between adhering to scientific standards and being intelligible for a wider non-expert readership. Students of Energy and Environmental Technology at the school of engineering (FHNW) in Switzerland write a total of six technical reports about their project work (mostly in German). By analysing two management summaries, the focus is laid on the lecturers' approach of relying on formative feedback which supports and accompanies the students' iterative writing processes. It is shown how in early semesters lecturers provide hands-on guidance, such as suggesting discourse markers or pinpointing vague references to sharpen students' awareness of the need to write as concisely as possible for mixed audiences.
\end{abstract}

\section{Introduction}

Graduates of Swiss Universities of Applied Sciences and Arts receive practice-oriented training, making them directly employable by the industry. As students proceed in the course of their studies, they need to become not only functional members of their academic discourse communities but also have to ingrain themselves in the writing practices of their future workplaces. As engineers in the industry, they will encounter an array of readers of their documents in their workplaces, which may range from clients, vendors to governmental institutions. This act of juggling the needs of diverse stakeholders is a particular challenge when writing up technical reports (Foster, 2017; Laplante, 2018).

In the School of Engineering of FHNW, students practise academic and professional writing by engaging in project work, where they communicate their final research findings in the form of technical reports (mostly in German). The projects are frequently commissioned by external clients and are of particular significance because they account for $25 \%$ of the credits that students obtain. Most external clients do not have a scientific background, requiring students to have their lay audience in mind when writing their final reports. Therefore, academic writing lecturers coach and support students on how to make specific textual components, such as the management summary, the introduction and the recommendations, relevant to and accessible for non-experts (Foster, 2017). Management summaries, in particular, have become a focal point in sensitising students to a mixed readership because lay audiences are likely to rely heavily on this document. 
Thus, our article aims to show how Engineering students of Energy and Environmental Technology grapple with the linguistic and structural challenges of tailoring their writing to conform to disciplinary conventions but also to be understandable for lay audiences. Our primary focus will lie on presenting our experience-based writing process approach within the students' project work by discussing two examples of students' management summaries. We illustrate our feedback and examples of specific suggestions for keywords or conventional wording that instigated the reviewing process of the text. In the following sections, disciplinary conventions regarding language and technical reports are summarised. Subsequently, we make the link to what the implications are for teaching academic writing to the engineering students of Energy and Environmental Students at FHNW. Thereby, we reflect on how the students' extensive training in project management can be connected with academic writing.

The following observations are based on a conjoined experience of coaching about 80 student projects and more than 40 technical reports, written between the years 2016 and 2019 in Energy and Environmental Technology, during which we have developed and honed our feedback practices. About $70 \%$ of the projects were commissioned by external clients.

\section{Writing as Engineers: Disciplinary Expectations for Technical Reports}

Technical reports, which document the findings of finished projects, often follow the structure of scientific journal articles (Foster, 2017). Foster (2017, p.105) suggests that technical reports tend to contain the following eleven elements (excluding formalistic and optional parts): title, abstract, executive summary, introduction, methods, results, discussion, conclusions, recommendations, references, appendices.

In technical reports, the chapters 'methods', 'results', 'discussion' and 'conclusions' are the core scientific chapters, which are built upon each other and require expert knowledge to follow as readers. Recommendations and executive summaries, on the other hand, are to be accessible to a broader readership, which means they should be stand-alone texts, allowing a nonspecialist audience to read the report selectively (Foster, 2017).

Writing manuals for scientists and engineers detail comprehensive lists of guidelines when writing technical reports regarding style and structure (e.g., Foster, 2017; Hopkins \& Reid, 2018). Laplante (2018, p. 37) succinctly summarises these characteristics as "the 5 Cs of technical writings". Each C stands for one essential feature: (1) correct, (2) clear, (3) complete, (4) consistent, (5) changeable. The first two points concern language use, which should be correct and unambiguous. Other writers pinpoint that technical writing needs to be concise and precise. As everyday language tends to be generalising or vague, succinct writing requires extensive training (Hopkins \& Reid, 2018; Karras, 2017). Point three, completeness, refers to how texts must include all relevant information, offering complete and coherent insight into the research undertaken. Even though completeness pertains to content, it is also interwoven with the second point, clarity. For instance, coherence can be made explicit by using cohesive devices and comprehensibility can only be met if sentences and lexical items are employed which are understandable for readers.

The fourth point, consistency, refers, on the one hand, to the internal organisation of the text, as individual sections should be linked and not contradict each other. On the other hand, consistency also includes an external dimension, whereby the text needs to follow applicable standards. Laplante's final feature, "changeability" (2018, p. 39), is fairly pragmatic as it points to a technical and formal dimension. In other words, the document is stored in a standard electronic format, and it is compatible with most word processing programmes. Thus, the document is required to be readily adaptable in case of modification.

In short, professional and academic expectations are that technical writers convey complex subject matters in a concise and understandable style, with a coherent line of argumentation. 


\section{Writing Challenges for Students of Energy and Environmental Technology}

In their first four projects, students of Energy and Environmental Technology usually work in teams of three to five students. As such, they may approach writing differently and may have diverging ideas about how to manage a project or how to answer a scientific question successfully. Further, students may not have the same level of experience in academic or collaborative writing. All students have previous work experience during which the majority also had to write short texts.

In their projects, students investigate and discern possibilities for optimising processes, such as performing a lifecycle analysis, proposing alternatives to fossil fuel-intensive means of production, or feasibility studies. Subsequently, they document their findings. In other words, their technical reports are mostly the final and only output/product for their clients, which means their importance cannot be overstated. At the same time, these reports have to meet disciplinary and academic standards, for which scientific project supervisors act as gatekeepers. Thus, students need to master both scientific and professional writing practices.

Consequently, while students strive to succeed academically, they can never lose sight of their actual clients, which may prove to be a highly demanding task. Depending on the clients' technical expertise, their interests, or even their societal role, students must align their writing accordingly. For instance, the degree of technical jargon used can vary considerably depending on the readership since previous projects included a diverse clientele, ranging from farmers, local policymakers, foresters to the head of studies.

As a result, the executive/management summary has become one of the critical documents, emphasising research findings in an easily digestible way. Students need to write self-contained texts, which concisely summarise the initial situation, methods employed, main results and recommendations for informed readers. These summaries are expected to be organised into sections, featuring clear headings for reader guidance (Jörissen \& Lemmenmeier, 2016).

\section{Aligning Teaching (Academic) Writing with Project Management Models}

Our tasks as instructors of academic writing are multi-faceted, including giving classroom lectures, providing feedback during the writing process and grading the reports as regards academic literacy and writing competency. This compound of methods is designed to cater to students' needs, helping them to navigate through the expectations of varied audiences.

Karras (2017, pp. 206-208) has shown that engineers are planning their writing processes in a structured and purposeful way. In their professional practice, engineers often write under pressure with tight deadlines, successively updating and adding to reports once new data from a project are gained. In the context of Energy and Environmental Technology at FHNW, teaching academic writing needs to be compatible with project management models, which are conveyed in class as from year 1 . While students receive some set deadlines for individual deliverables, they are expected to plan and manage their schedules according to project management principles. As Stöhler et al. (2018) suggest, a report should be considered a separate project within the scientific project itself. Thus, we think it may be helpful for students if teaching methods in academic writing follow the process of projects themselves - right in line with the basic model of a writing process consisting of planning, composing and reviewing, as described by Flower and Hayes (1981).

In fact, in our role of lecturers, we try to draw students' attention to synergies between writing and project management. For instance, in their stakeholder and risk analyses - an essential component of project management - students have to reflect in detail on who their addressees are, how to manage their expectations and how to deal with potential problems. Once students have described their stakeholders, they have also completed a step in their planning phase for the technical report, in that they know their audiences and can proceed with their writing. Of course, during the writing and research process, students need to revisit and potentially adapt 
their stakeholder analysis and consequently their audience descriptions. While it may at times be challenging for students to keep their stakeholders in mind, regular meetings with clients and coaches help students picture their readership during the writing process in an exceptionally close way, in our experience.

To guide writing processes and to establish and maintain a dialogue about necessary adaptions, we regularly meet with individual project teams, coaching them on matters of academic writing but also on expectations of supervisors, clients and of other stakeholders. Our coaching role provides students with the opportunity for reflection, feedback, decision-making, problem solving and conflict solving (see model by Stöhler et al., 2018, p. 275). As students progress in their studies, they have fewer mandatory meetings. In many instances, they have grown accustomed to organising their writing process. In fact, they tend to have the idea of audiences as stakeholders ingrained by the time they reach the bachelor level.

\section{Illustration of Writing Process Approach}

The following sections will illustrate our writing process approach and how it supported students in meeting disciplinary writing demands and making them familiar with academic conventions. Further, we will also address how students overcome the challenge of addressing a mixed audience. Therefore, we will look at management summaries by two project teams from the first and second semester, respectively. The following reflective analysis is divided into the three steps we usually undertake when getting students' drafts: Firstly, we will focus on our impression of drafts. Secondly, we will describe what linguistic aspects we wanted students to improve, for which we relied on the writing manuals introduced above (Foster, 2017; Laplante, 2018). Finally, we show how we provide, sometimes fairly specific, in-text feedback and how, after several feedback loops, students incorporate our suggestions and fine-tune their texts.

\section{Example 1}

Example 1 is from a first-semester project in the spring semester 2019 (see Figure 1). Project 1 aims at teaching students the basics of project management. Thereby, students experience the different stages within a project and practise relevant skills at least once before dealing with actual clients. Students can choose their own topics, they establish the goals and determine the scope of their project in discussion with the project management lecturer, who, at the same time, is their fictitious client. As one part of this dry-run, students need to summarise their findings succinctly by writing a management summary. Therefore, they have attended a 45minute lecture on language and structure, including an analysis of a student's management summary from previous years. Coaches provide formative feedback on the first draft(s) to help students become accustomed to editing processes and to writing disciplinary content.

The students of this particular group were interested in assessing activities responsible for carbon emissions. Moreover, they investigated to what extent reforestation could help reduce the carbon footprint, calculating the potential of forests as carbons sinks in Switzerland. When handing in their first draft (see Figure 1), the group had already compiled their results and was in the process of consolidating their findings. 


\section{Figure 1}

Screenshot of the First Draft

\section{Management Summary}

\section{Ausgangslage}

Das Klima und dessen Schutz ist ein Thema, sind Themen, welche zunehmend an Wichtigkeit gewinnen. Der Schaden am Ökosystem muss auf ein Minimum reduziert werden, um die Welt wie wir sie kennen erhalten zu kömnen.

Pflanzen binden $\mathrm{CO}$, in Biomasse während sie wachsen und je grösser die Masse der Pflanzen, desto grösser ist die Aufnahme von $\mathrm{CO}_{2}$ grundsätrlich. Um welche Menge könnte also der Netto-CO,-Ausstoss der Schweiz gesenkt werden, indem aufgeforstet wird?

Da es ist nicht immer einfach abruschätzen, welche Aktivicäten besonders grosse Mengen an Treibhausgrsen produzieren und bei welchen Aktivitaten laum relevante Mengen freigesetat werden. Ziel dieser Arbeit ist es einen Vergleich rwischen verschiedenen Aktivitäten zu erstellen und herauszufinden, welchen Beitrag Waldtiächen zur Kompensation leisten könnten. Zur Veranschaulichung wird der Treibhausgasausstoss der gewalklten Aktivitaten, zusammen mit der zur Kompenszation benötigten Waldfläche dargestellt.

\section{Vorgehen}

Der Beriche umfasst Daten zu Aktivitäten oder Verhaltensweisen, welche sich in die Bereiche Errahhrung Mobilitït und Wohnen einordnen lassen. Für jeden Bereich sind Aktivitäten behandelt, welche in der Schweiz besonders relevant sind, weil sie entweder häufig aufauchen, grosse Mengen Treibhausgase produxieren oder bei einem grossen Teil der Bevölkerung Irrglauben vorliegen.

Zur Bestimmung der Senken- oder Kompensationsleistung eines Quadratmeters Wald, wurde der wirtschaftliche Ertrag der Schweizer Walder (8.2 Mio. $\mathrm{m}^{2} /$ )ahr) durch die vorhandene Waldfäche geteilt (1.31 Mia ha). Somit sind die verschiedenen Waldbewirtschaftungsarten berücksichtigt und es kann von einem durchschnietlichen Ertrag der Schweizer Wallder ausgegangen werden.

Hauptergebnisse

Die CO2-Senkenleistung nimmt mit zunehmendem Alters eines Waldes ab, bis sie gegen Ende komplect versiegt: Walder bieten daher keine nachhaltige KIImaschutamassnahme, können allerdings einen Puffer bieten, bis das Verhalten der Menschen sich genug verändert hat oder eine höhere Menge klimafreundliche Energie produziert wird. Um das Potential zu erhähen, kam das Holx zu Produkten weiterverarbeitet oder als Baustoff verwendet werden. Durch die Verwendung von Holz werden die Emissionen verringert, welche bei der Produktion oder Verbrenwung anderer Materialien entstehen würden. Je nach Bewirtschaftung und Nutzung eines Waldes, ist also die Emissionsverringerung pro Fläche stark unterschiedich

Da die Schweiz es richt vorsieht, eine grosse Menge an Stakervoildeg, anzupflanzen oder zu bewirtschaften, basieren die Berechnungen und Gegenüberstellungen auf der Arnahme, dass die rusätzlich angepflanate Waldtiache energetisch verwendet wird und dabei fossile Energieträger ersetzt. Bei der energetischen Nutzung

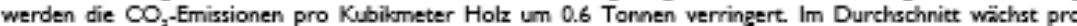
Quadratmeter Schweizer Wald im Jahr $0.0006 \mathrm{~m}^{2} \mathrm{Holz}$ entsprechend werden pro $\mathrm{m}^{2}$ Waldflïche $0.36 \mathrm{~kg} \mathrm{CO}$ Emissionen pro jahr oder pro ha Waldfläche 3.6 Tonnen $\mathrm{CO}_{2}$-Emissionen kompensiert.

Note. Screenshot of the first draft of the completed management summary.

Firstly, as shown in Figure 1, the draft already conforms with the basic structural conventions of management summaries since the text is divided into sections with understandable and sensible headings. However, the first section needs editing, given that there are three miniparagraphs, which suggests poor paragraphing. Further, students have not proposed any recommendations yet, thus not fulfilling the criterion of completeness.

Secondly, the summary's explanatory power could be enhanced concerning clarity and completeness (see Laplante, 2018). One of the lecturer's comments was that their results needed to be quantified if possible, as circled in the comment in Figure 2. 
Figure 2

Comment by the Lecturer

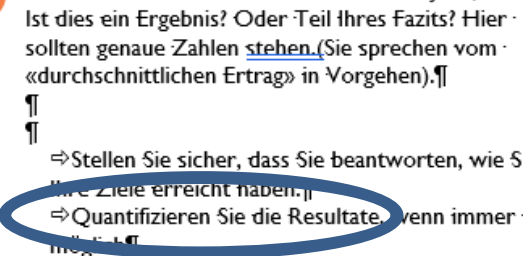

Note. Comment by the lecturer in the results section (circle added).

The results paragraph did not list concrete findings but was already a discussion of the implications of the students' project. Hence, students had forgotten to share important parts of their calculations, in which they had compared reducing the carbon footprint through small lifestyle changes to the potential of forests as carbon sinks. The lecturer pointed this out by adding comments in the reviewing mode (see Figure 2). Students accommodated this feedback by including bullet points with exact figures in their second draft. What is remarkable, however, is that students took on this requirement for precision and inserted quantitative modifiers wherever possible throughout the entire document. For instance, in their methods section, students initially wrote that they wanted to analyse lifestyle behaviours from areas of nutrition, mobility and housing, "because these areas are responsible for a big part of carbon emissions in Switzerland". After the first feedback loop, students quantified their statement "behaviours, which make up $75 \%$ of Swiss carbon emissions".

Thirdly, to meet the disciplinary standards of correctness (Laplante, 2018), students needed to rid their text of generalisations. For instance, they claimed that "a big part of the population had misconceptions" of what caused carbon emissions. Thus, in the first feedback round the lecturer admonished them to "be wary of generalisations". Consequently, students deleted the phrase entirely in their second draft, for they had realised that their assessment was based on their own inkling without proper scientific backing.

Finally, it is essential to note that, despite intensive rounds of feedback, students remained in charge of their authorial roles. For instance, the lecturer pointed out that the sub-clause "to preserve the world as we know it" was a cliché. Nevertheless, the students felt that it was a vital sentiment and decided to leave it in. While the lecturer was not enthused about the wording, it underlines that students owned their texts and hopefully carefully reflected on the feedback given.

\section{Example 2}

The second example shows the revision process of a management summary in a team's first report with external clients. In spring 2018 a Municipal Waste Management Association in the university's area asked a team of five students to conduct a material flow analysis and a survey in their municipalities about the acceptance of plastic recycling. The team completed the project with a 50-page project report, including a management summary. They did not receive further instruction but had a mandatory deadline to submit a first draft, which led to written feedback by the communication lecturer. The first draft comprised two pages of text and, at first glance, conformed with the typical structure of a four-section management summary (Figure 3 ). 


\section{Figure 3}

Screenshot of the First Draft
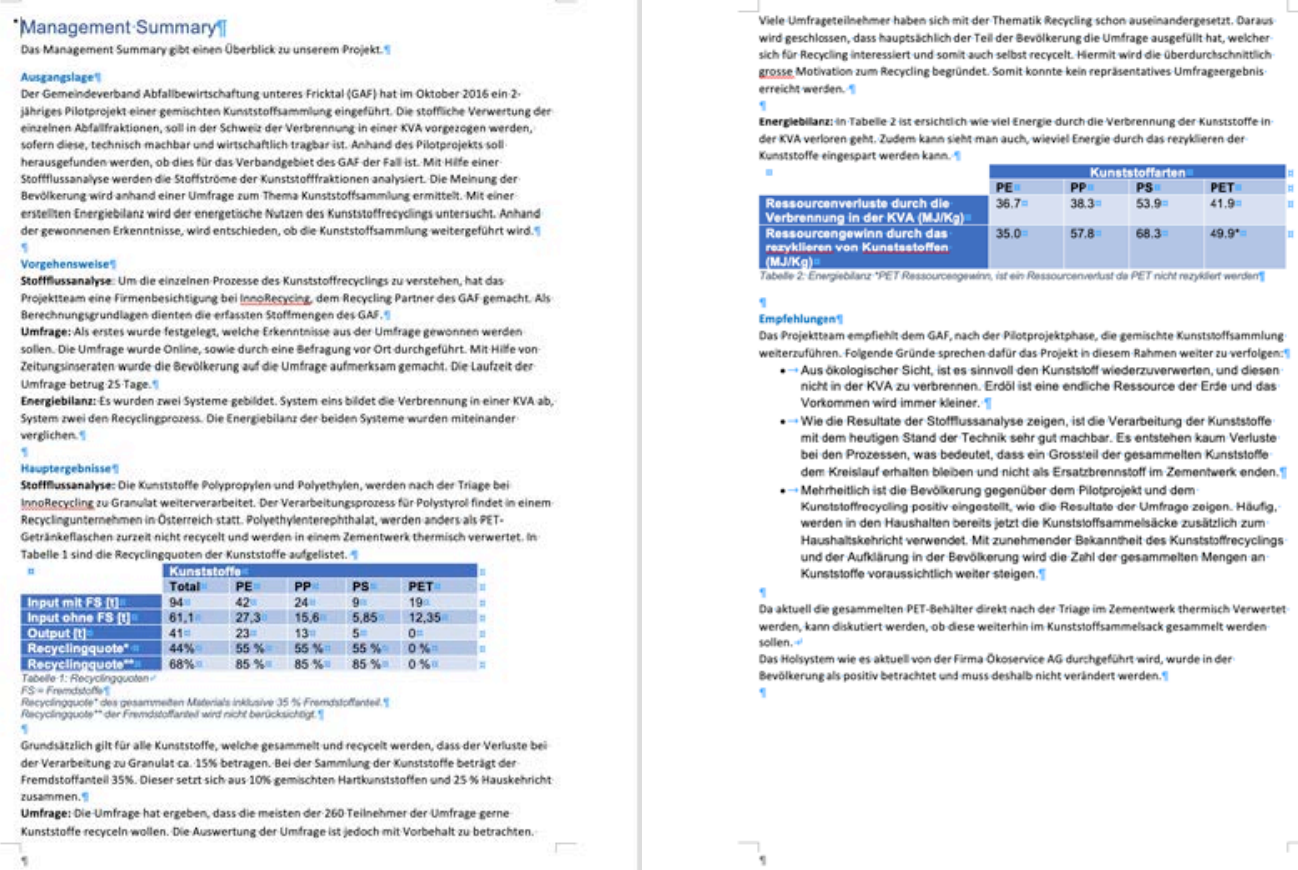

Note. Screenshot of the team's first draft of the management summary.

In many parts, however, the language was neither succinct nor precise, which resulted in overly long sentences and poorly structured sections. For example, the first section did not differentiate between the waste management association's pilot project and the students' project: "The pilot project aims to find out whether this [high energy efficiency for plastic recycling] is the case for this municipal waste association. A material flow analysis is used to analyse the material flow of plastic functions." If the second sentence had started with "The aim of this study is a material flow analysis" (Ziel), reading guidance would have been ensured. In the same section, students wrote about different aims but did not structure them (Figure 4). The lecturer suggested making this part more concise and coherent by adding discourse markers, such as 'firstly', 'secondly' etc. (erstens, zweitens, drittens).

\section{Figure 4}

\section{First Feedback}

KVA vorgezogen werden, sofern diese technisch machbar und wirtschaftlich tragbar ist. Anhand des Pilotprojekts soll herausgefunden werden, ob dies für das Verbandgebiet des GAF-der Fall - ist. ๆ Ziel der-vorliegenden Untersuchung war-es-erstens, die-Stoffströme der Kunststofffraktionen mit. einer-Stoffflussanalyse-zu eruieren. Zwweitens'....Die Meinung der Bevölkerung wird anhand einer Umfrage -zum Thema-Kunststoffsammlung ermittelt. Drittens'...Mit einer erstellten Energiebilanz wird der energetische Nutzen des Kunststoffrecyclings untersucht. Die Erkenntnisse-dieser. Untersuchung.sind.Entscheidungsgrundlage.für..... -ृ

Note. Feedback by lecturer given in track mode.

These alterations were given in track mode in one section to exemplify how readers' guidance could be increased. Our experience has shown that novice writers are insecure about how to guide readers, and providing students with concrete discourse markers or conventional wording 
on an exemplary basis in their first couple of projects helps improve students' writing proficiency.

Also, the first draft consisted of rather general sentences, as shown in the following:

The results of our material flow analysis show that the processing of plastics can easily be done with current technology. There are nearly no losses during these processes, which means that a big part of the collected plastics can be kept in the lifecycle and will not end as fuel in a cement plant.

General sentences on petroleum and phrases such as "can easily be done", "nearly no losses", "a big part" do not meet the needs for correctness and clarity in technical writing (Laplante, 2018). Thus, the lecturer singled out non-succinct vocabulary, asked for specific examples, percentages, or numbers to rephrase sentences, to make results concrete (see Figure 5).

\section{Figure 5}

Lecturer Proposing Alternative Vocabulary

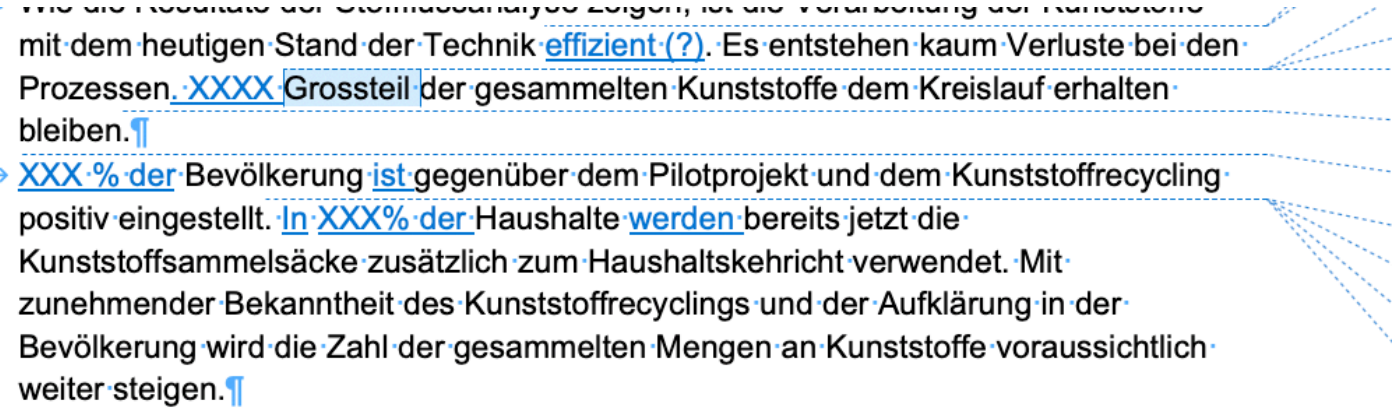

Note. Lecturer proposing alternative vocabulary to enhance succinctness.

Two feedback loops were necessary to make the first (insufficient) draft acceptable to submit to clients. After students restructured their management summary, shortened and cut sentences, and used more succinct vocabulary, it became a well-readable text, which was understandable for a mixed audience. Moreover, having given iterative feedback enabled the scientific supervisor and the communication lecturer to assess and grade strictly, requiring students to uphold high standards for the whole technical report.

Just a few weeks after submission, a local newspaper article was published. The journalist read the management summary (and most likely not much more of the report) and cited parts of it in her newspaper article (Böni, 2018). This fact nicely illustrates how important it is to polish management summaries in iterative loops, whereby making it gradually more accessible to wider lay audiences.

\section{Conclusions}

Teaching technical writing needs to take into account the practices in and cultures of project management for engineers, as well as special requirements for technical genres. At Swiss universities for applied sciences, research generally addresses real problems in the industry or is linked to policymaking. Therefore, students face a double challenge of simultaneously needing to prove and enhance their competencies in scientific research methods, while also catering to and communicating their results effectively to their clients. In addition, students continuously work at streamlining their writing process to become as efficient as possible (Karras, 2017). By analysing two management summaries, we have attempted to illustrate how a writing process approach to scientific writing skills may help make key elements of a technical report accessible to mixed audiences. In addition, by giving students specific feedback to be 
more precise, to simplify their lexicon and to structure their writing in a reader-friendly way, we hope that students never lose sight of their uniquely heterogeneous readership.

Additionally, we believe that our feedback strategies of inciting students to reflect on or revise a section or of even providing fairly specific discourse markers assist students in improving coherence, in using succinct vocabulary and ultimately in honing their writing skills. We plan and hope to study the effectiveness of said strategies in more depth. Loops of written feedback may help familiarise students with academic and professional writing practices, for instance, by providing genre-specific vocabulary, students may not know yet. Still, students are in charge of their authorial role: feedback is always given on an exemplary basis. Finally, the excerpt from a local newspaper underlines how crucial it is to write understandably and succinctly. If put in a nutshell, students' management summaries may even catch the attention of local journalism. 


\section{References}

Böni, N. (2018, June 28). Gutes Zeugnis für die Kunststoffsammlung, Aargauer Zeitung.

Flower, L., \& Hayes, J. R. (1981). A Cognitive Process Theory of Writing. College Composition and Communication, 32(4), 365-387.

Foster, D. H. (2017). A Concise Guide to Communication in Science \& Engineering. Oxford University Press.

Hopkins, D., \& Reid, T. (2018). The Academic Skills Handbook. Sage.

Jörissen, S., \& Lemmenmeier, M. (2016). Schreiben in Ingenieurberufen. Praxishandbuch für Ausbildung und Arbeitswelt ( $3^{\text {rd }}$ ed.). hep Verlag.

Karras, S. (2017). Wie schreiben Ingenieure im Beruf? Ein arbeitsplatzbezogenes Kommunikationsprofil. Waxmann.

Laplante, P. A. (2018). Technical Writing: A Practical Guide for Engineers and Scientists. (2 ${ }^{\text {nd }}$ ed.). CRC Press.

Stöhler, C., Förster, C., \& Brehm, L. (2018). Projektmanagement lehren. Studentische Projekte erfolgreich konzipieren und durchführen. Springer. 